\title{
Mapping magnetic lineaments and subsurface basement beneath parts of Lower Benue Trough (LBT), Nigeria: Insights from integrating gravity, magnetic and geologic data
}

\author{
Mukaila Abdullahi ${ }^{1,2, *}$, Upendra K Singh $^{1}$ and Ravi Roshan ${ }^{1}$ \\ ${ }^{1}$ Department of Applied Geophysics, Indian Institute of Technology (ISM), Dhanbad 826 004, India. \\ ${ }^{2}$ Physics Unit, Department of Science Laboratory Technology, Modibbo Adama University of Technology, \\ Yola, Nigeria. \\ *Corresponding author. e-mail: mikaildaddy1@gmail.com
}

MS received 12 January 2018; revised 25 April 2018; accepted 25 April 2018; published online 11 December 2018

In this study, we present the analysis of the aeromagnetic data of parts of the Lower Benue Trough. Lineament analysis of the aeromagnetic data demonstrated four tectonic trends of the basement terrain. The lineaments are in the northeast to southwest (NE-SW), east, northeast to west, southwest (ENEWSW), north to south (N-S), and east, southeast to west, northwest (ESE-WNW) directions. The NE-SW and ENE-WSW are the most dominant whereas the N-S and ESE-WNW are the minor trends. The estimated magnetic basement using spectral analysis vary between 3.5 and $5 \mathrm{~km}$ and the shallow magnetic sources (depth to top of intrusions) vary between 0.24 and $1.2 \mathrm{~km}$. The result of the basement estimation from the magnetic data is comparable with the previous results from other studies as well as with the basement depth estimated from the gravity data of part of the present study area are incorporated in the study. From the gravity data, we identified sub-basin around Makurdi and basement of the sedimentary basin $(5 \mathrm{~km})$ is estimated using GPSO algorithm and Oasis Montaj (Geosoft).

Keywords. Aeromagnetic data; Benue Trough; vertical derivative; magnetic lineaments; GPSO; inversion of gravity data.

\section{Introduction}

Magnetic measurements and interpretations play an important role in understanding the variations in earth's magnetic field resulted from the underlying basement rocks' magnetic properties (magnetic susceptibilities), geological structures and their geometric shapes and sizes (Abdelrahman et al. 2007, 2012; Abdelrahman and Essa 2015; AboEzz and Essa 2016; Biswas 2016; Biswas and Acharya 2016; Essa and Elhussein 2017). At short wavelengths, the data reflect the susceptibility changes that could be associated with the sedimentary rocks and at long wavelengths the magnetic anomalies could reflect the susceptibility changes in the underlying basement (metamorphic and basic igneous) rocks (Telford et al. 1998). Magnetic data allow us to delineate the lateral changes in susceptibility associated with the underlying structures and by doing so information about the structural trends and its lithological changes can be inferred. To delineate the subsurface structural features from magnetic data, numerous magnetic edge enhancing techniques have been developed 
and used by many researchers (Nabighian 1972; Cordell and Grauch 1985; Roest et al. 1992; Phillips 1998; Verduzco et al. 2004; Salem et al. 2007).

Gravity method plays a vital role in recognition of sedimentary basins (Rao et al. 1994; Ali et al. 2014). There are varieties of techniques and methods for the interpretation of gravity anomalies over or due to sedimentary basins (e.g., Rao et al. 1993, 1994; Chakravarthi 1995; Chakravarthi and Sundararajan 2005). The structure of the sedimentary basins is often derived from the gravity anomalies with constant density contrast throughout the section of the basins (Bott 1960). However, the density contrast of sedimentary rocks is not practically constant (Rao et al. 1993, 1994; Chakravarthi 1995; Chakravarthi and Sundararajan 2005).

The Nigerian Benue Trough is of economic importance for its mineralization potential. It is an elongated rift system, which trends roughly in the NE-SW direction. It is bounded to the NE by the Chad basin and to the SW by the Niger Delta region. The origin of the trough was firstly proposed by King (1950). Stoneley (1966) and Wright (1968) put forward the graben origin of the trough relating it to the readjustment of the African plate after the Cretaceous opening of the Gulf of Guinea. The Benue Trough has been divided into three sub-troughs, viz., the Upper Benue Trough (UBT), Middle Benue Trough (MBT) and the Lower Benue Trough (LBT) as shown in figure 1. The trough is filled in with Cretaceous sediments of Albian to Maastrichtian ages of $6 \mathrm{~km}$ in the Lower Benue Trough, $5 \mathrm{~km}$ in the Middle Benue Trough and $4 \mathrm{~km}$ in the Upper Benue Trough (Ofoegbu 1984; Ofoegbu and Onuoha 1991). Granites and gneisses made up the Precambrian crystalline basement rocks (figure 1) (Ofoegbu 1984). The intruded basement Quaternary volcanism consists of numerous granitic intrusive to thin dyke-like bodies and basaltic lavas (Nwachukwu 1972; Uzuakpunwa 1974; Olade 1978; Adighije 1981).

Number of published magnetic data (Anudu et al. 2014; Oha et al. 2016) have studied the basement structures beneath parts of the Lower Benue Trough (LBT). Anudu et al. (2014) and Oha et al. (2016) delineated five geological lineaments trending NE-SW, NW-SE, ESE-WNW, ENE-WSW and $\mathrm{N}-\mathrm{S}$. In this paper, we attempted revising the concealing basement structures beneath parts of the LBT using the high-resolution aeromagnetic data and interpreted in terms of the geological history of the region. We used qualitative analysis of the magnetic anomaly in order to extract the structural trends in our interpretation approach. We performed the spectral analysis and computed

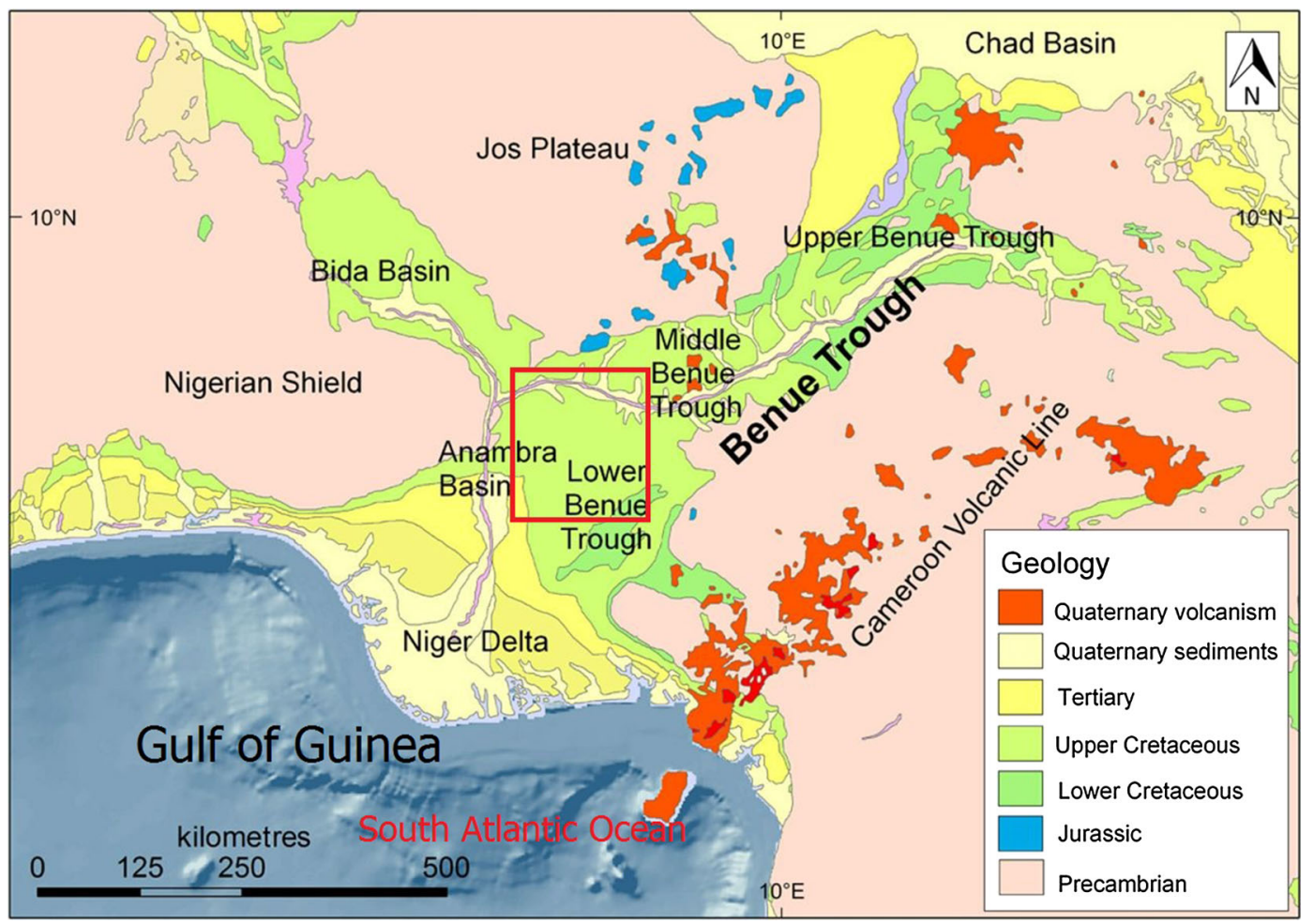

Figure 1. Geological map of Benue Trough. Red box shows the study area. 
the depths to the top of the causative sources over the study area. We interpret the estimated depth values in terms of the basement and shallow magnetic sources (intrusions). We have also done inverse modelling of the gravity data using GPSO and Oasis Montaj (Geosoft).

\section{Geology and tectonics of the study area}

The origin and sequence of events that lead to the development of the Nigerian Benue Trough have been well discussed and published by authors (King 1950; Stoneley 1966; Wright 1968; Nwachukwu 1972; Olade 1978; Benkhelil 1982, 1989; Ofoegbu 1984, 1985; Guiraud and Maurin 1992; Anudu et al. 2014). The study area (Lower Benue Trough) is underlain by deposited sequence of Cretaceous sedimentary rocks. Figure 2 depicts the geological map of the study area with the Cretaceous formations from the Asu River group up to the Nsukka formation been in order of their decreasing age. The Precambrian basement complex is made up of essentially, the granitic and magmatic rocks as can be seen from the eastern and the southeastern margin of the map (figure 2).
The Asu River group formed the oldest Cretaceous sediment in the region. It consists of shale and limestone with intercalations of sandstone. The shales have been highly fractured and are fissile in nature (Ofoegbu and Onuoha 1991). The Eze-Aku shale consists of black shale, siltstone and sandstones whereas the Eze-Aku sandstone consists mainly of sandstones. Awgu Formation is made up of shale and limestone of Coniacian age. The Awgu Formation is overlain by the Nkporo Formation of mainly shale and mudstone. Bassange Formation consists of sandstones and ironstones, whereas the lower coal formation consists of coal, sandstones and shales. Nsukka Formation is made up of false-bedded sandstone of Campanian age.

The sediments are strongly affected by the intense compressional folding that occurred during the mid-Santonian tectonic episode leading to the production of the hundreds of anticlines and synclines (figure 2) (Nwachukwu 1972; Benkhelil 1989). This development is in connection to the complete orogenic cycle (sedimentation, magmatism, metamorphism and compressive tectonics) along this trough (Benkhelil 1988), which resulted

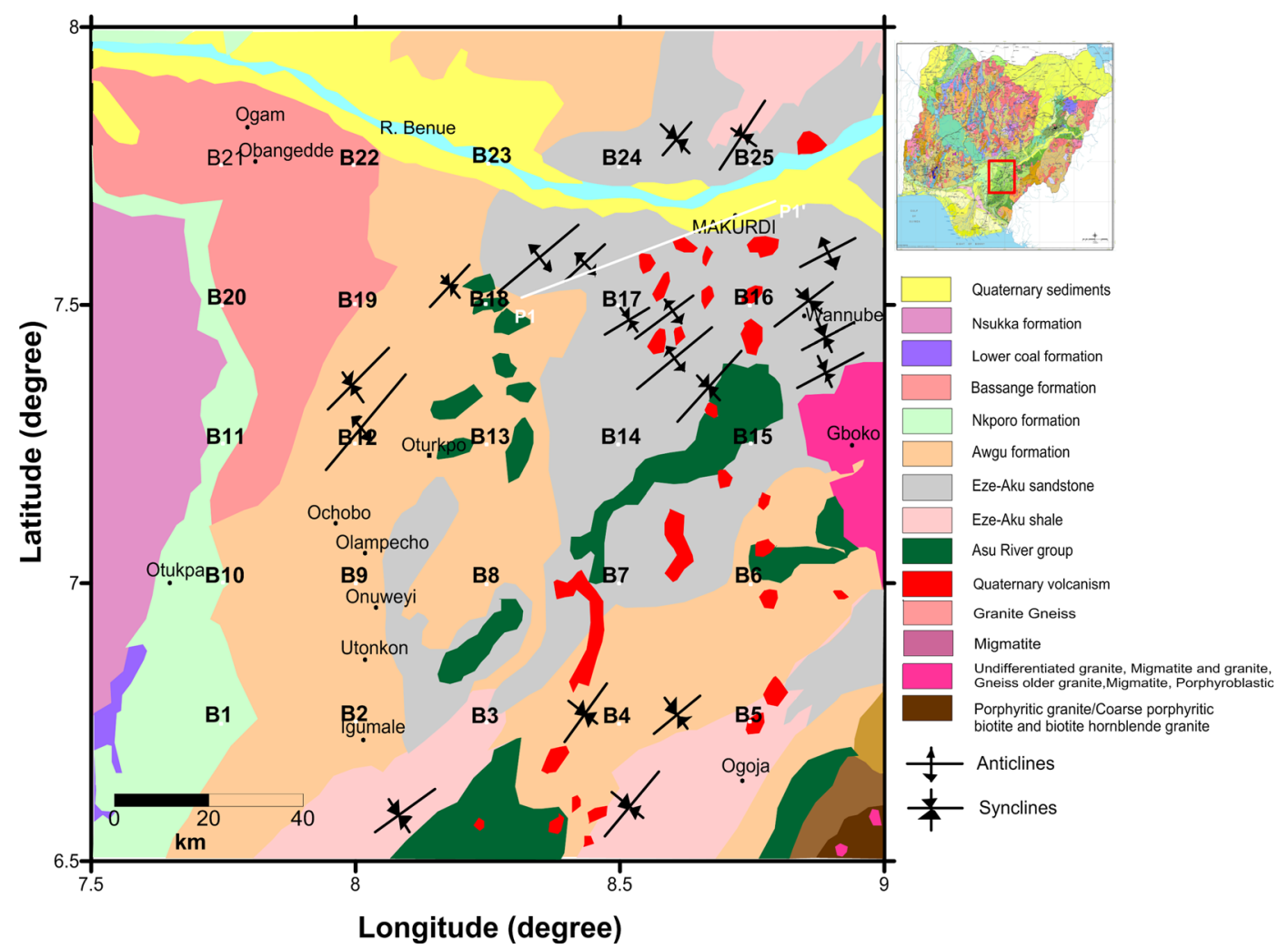

Figure 2. Sketch of the geological and tectonics of the study area (after Nigerian Geological Survey Agency 2009). The white dots shows the centre of blocks (e.g., B1, B2, ., B25). The white line (P1P1') shows the location of profile for the 2D gravity inversion. 


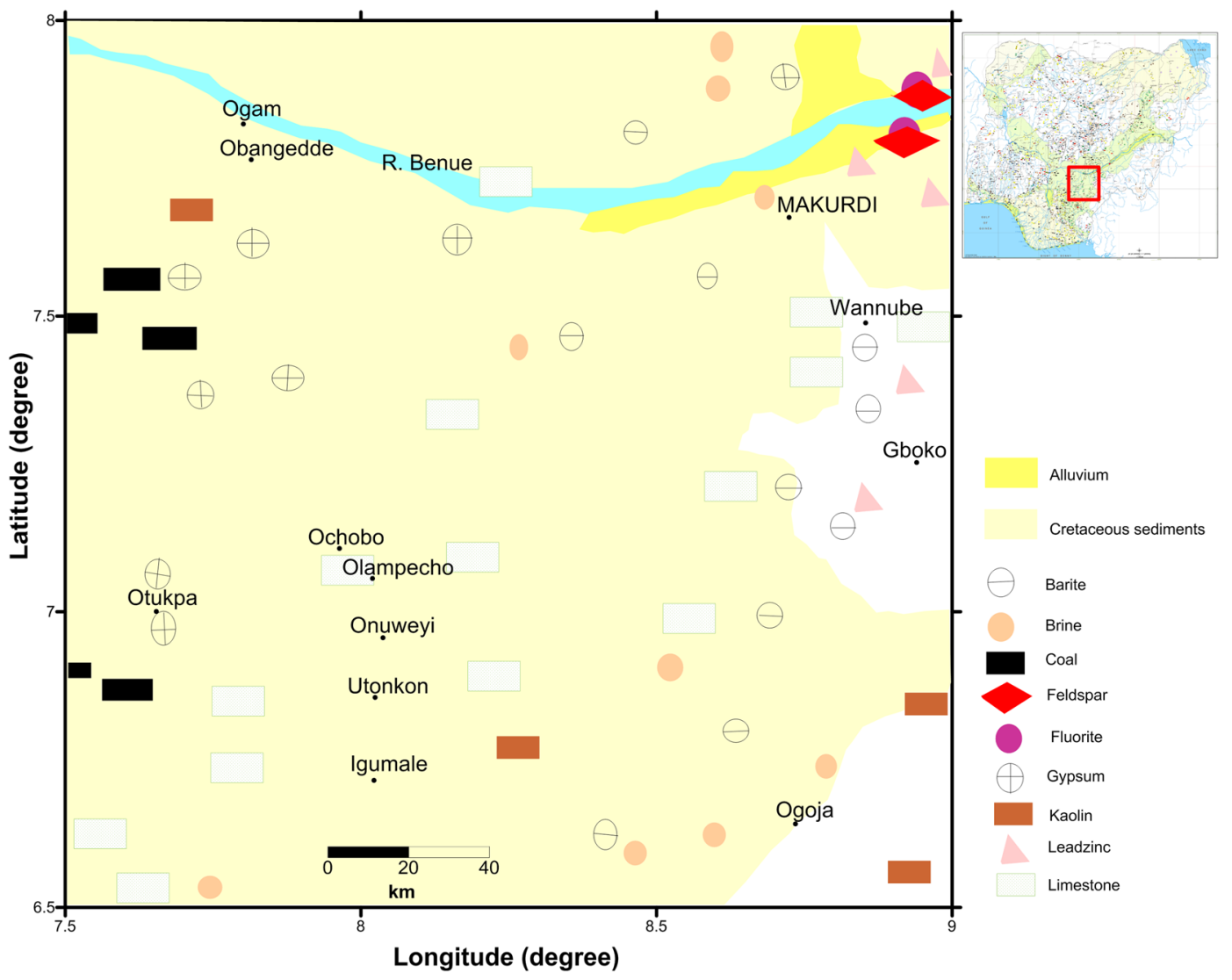

Figure 3. Sketch of the mineral resource map of the study area (after Nigerian Geological Survey Agency 2009).

to the numerous intrusive (mainly basalts) invaded the Awgu shale, Eze-Aku group and Asu River group (figure 2) (Ajayi and Ajakaiye 1981; Maluski et al. 1995; Anudu et al. 2014).

The Eze-Aku sandstone and the Albian Asu River shale are major host of lead-zinc, barite and fluorite and other metalliferous mineral deposits (figure 3) (Nwachukwu 1972; Akande et al. 1989; MMSD 2010).

\section{Analysis of high-resolution aeromagnetic data}

The entire country (Nigeria) is covered by highresolution aeromagnetic data through Nigerian Geological Survey Agency (NGSA). The data for this area was therefore arranged officially from the agency. The data is in its digitised form. Figure 4 shows the total aeromagnetic intensity (TMI) map of the area. Direct interpretation of total magnetic intensity can be very complicated due to the fact that interferences from many surrounding magnetic sources (such as pipe lines, power lines and railways and so on) can contribute to the observed magnetic anomalies.
Reduction to pole (RTP) is an operator that can take care of asymmetric nature of the anomalies and transform them to symmetric form, reproducing the magnetic anomalies with their magnetization centred over their causative sources (Rozimant et al. 2009). Figure 5 shows the reduced to the magnetic pole (RTP) produced at geomagnetic inclination of $15^{\circ}$ and amplitude correction of 40 . The map shows anomalies that are correlated to known geologies. From the map, we demarcated the areas of high magnetic anomalies into thirteen zones superimposed on them, the geological units. As it can be seen from the RTP map, the zone H4, corresponds to the Precambrian basement rocks. The zones $\mathrm{H} 3$ and $\mathrm{H} 6$ correlated very well with the intrusions in the Aghila Hills (Ofoegbu and Onuoha 1991) and Workum Hills (Ofoegbu and Onuoha 1991; Oha et al. 2016), respectively. Zone H5 correlates with Eze-Aku shale injected by intrusive rocks. The Cretaceous sedimentary rocks around Makurdi and Oturkpo are intruded by basalts (Maluski et al. 1995). Therefore, the high magnetic anomalies $\mathrm{H} 2$ and $\mathrm{H} 10$ are observed to be very well correlated with the volcanic rocks intruded in the Eze-Aku sandstone around Makurdi down 


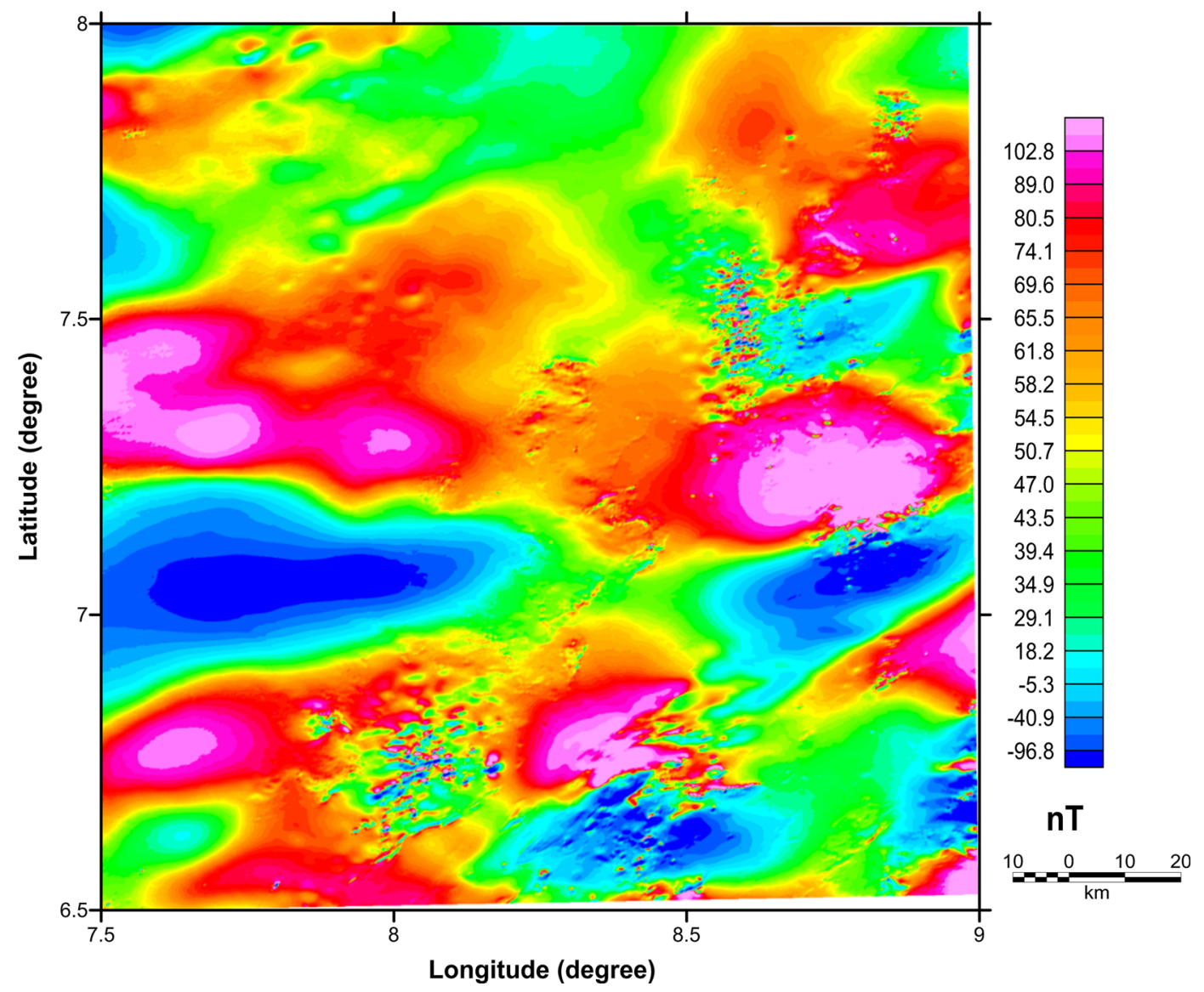

Figure 4. High-resolution aeromagnetic map of the study area.

to an area southwest of Oturkpo area. Volcanic intrusion has also been reported few kilometres (around $12 \mathrm{~km}$ ) north of Wannube (Ajayi and Ajakaiye 1981). The magnetic high, H1 could be due to the observed intrusions in association with lead-zinc (figure 3 ). The zone $\mathrm{H} 7$ does not correlate with any information on the present geological map, but may be due to some near surface intrusions around Igumale area (Oha et al. 2016). Zones H8, H9, H11 and H12 do not also correspond to information on the geological map. These could be interpreted due to an uplifted basement rocks. Zone H13 may be due to near surface basaltic lavas/sills and pyroclasts within the Cretaceous down to around Obangedde area (Anudu et al. 2014). The zones of low magnetic anomalies could be an area of thick Cretaceous sedimentary rocks.

\subsection{Vertical derivatives (VD)}

The partial derivative of magnetic data in the vertical direction is defined as what is referred to as the vertical derivative. This derivative emphasize the local anomalies by enhancing the high frequency (or short-wavelength) anomalies and suppresses the low frequency (or long-wavelength) anomalies in potential field data (Dobrin and Savit 1988). The first and second order vertical derivatives can be calculated respectively using the relations below

$$
V D=\frac{\partial^{n} \mathrm{~F}}{\partial z^{n}}=f^{-1}\left\{|k|^{n} f(F)\right\}
$$

where $F$ is the magnetic field, $f$ and $f^{-1}$ are the Fourier and inverse Fourier transforms, respectively and $|k|$ is the radial wave number. Here $n$ is the order of the vertical derivative (Blakely 1995; Ekinci et al. 2013; Ekinci and Yiğitbaş 2015).

Figure 6 shows the first vertical derivative (FVD) map of the RTP-TMI of the study area. Superimposed on the map, the volcanic intrusions and the associated minerals in the area. We zoned the areas affected by the intrusions. Zone 1 is observed to correlate with the lead-zinc mineralization, 


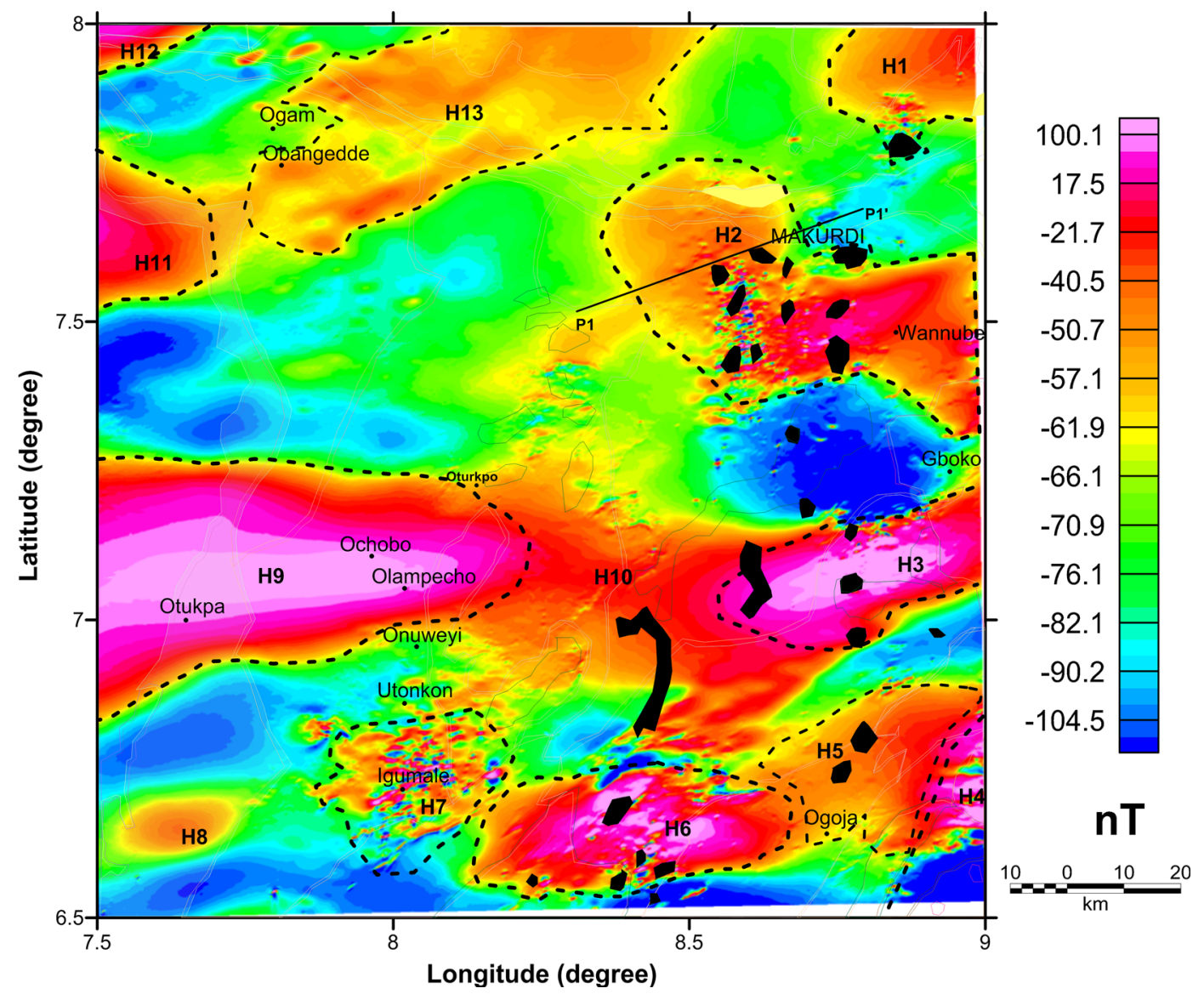

Figure 5. The reduced-to-pole map of the study area. The black line ( $\left.\mathrm{P} 1 \mathrm{P} 1^{\prime}\right)$ shows the location of profile for the $2 \mathrm{D}$ gravity inversion.

while zone 2 corresponds to an area of intrusions associated with lead-zinc. Zone 3 fall within an area of volcanic intrusions in association with barite and limestone. Zone 4 is due to intrusions associated with lead-zinc and barite. Zone 5 could be due to the Precambrian basement rocks associated with kaolin. Zone 6 correlates with intrusions and brine and barite. Zones 7, 9-13 do not correspond to any information on the geological map, but could be due to near surface intrusions associated with brine and limestone.

Figure 7 is the second vertical derivative (SVP) map of the RTP-TMI of the area. As on the FVD-RTP-TMI map, we have also superimposed on the SVD-RTP-TMI map, the volcanic intrusions and associated minerals found in the area. The SVD-RTP-TMI shows more emphases on the local anomalies and attenuated the signal due to the deeper features. On the map, we have also demarcated areas of volcanic intrusions and the associated minerals as in the case of the FVD-RTP-TMI (figure 6). These zones also followed the same explanation as in the preceding paragraph.

Magnetic lineament analysis is carried out on the SVD map. This is done by observing the trends and amplitudes of the anomalies that matches the geological history of the region. Figure 8 shows the interpreted magnetic lineament derived from the present study. It shows the prominent NE-SW and ENE-WSW trends and the subordinating ESEWNW and $\mathrm{N}-\mathrm{S}$ trends. The lineaments could be interpreted as the edges of geological bodies and directions of structures which might have been in connection with the thermo-tectonic events and the evolution of the sedimentary basins in the region.

\subsection{Spectral analysis}

Spectral analysis is a much known technique for the estimation of basement depth to anomalous sources (Bhattacharyya 1965; Spector and Grant 1970; Garcia-Abdeslem and Ness 1994; Maurizio et al. 1998). 


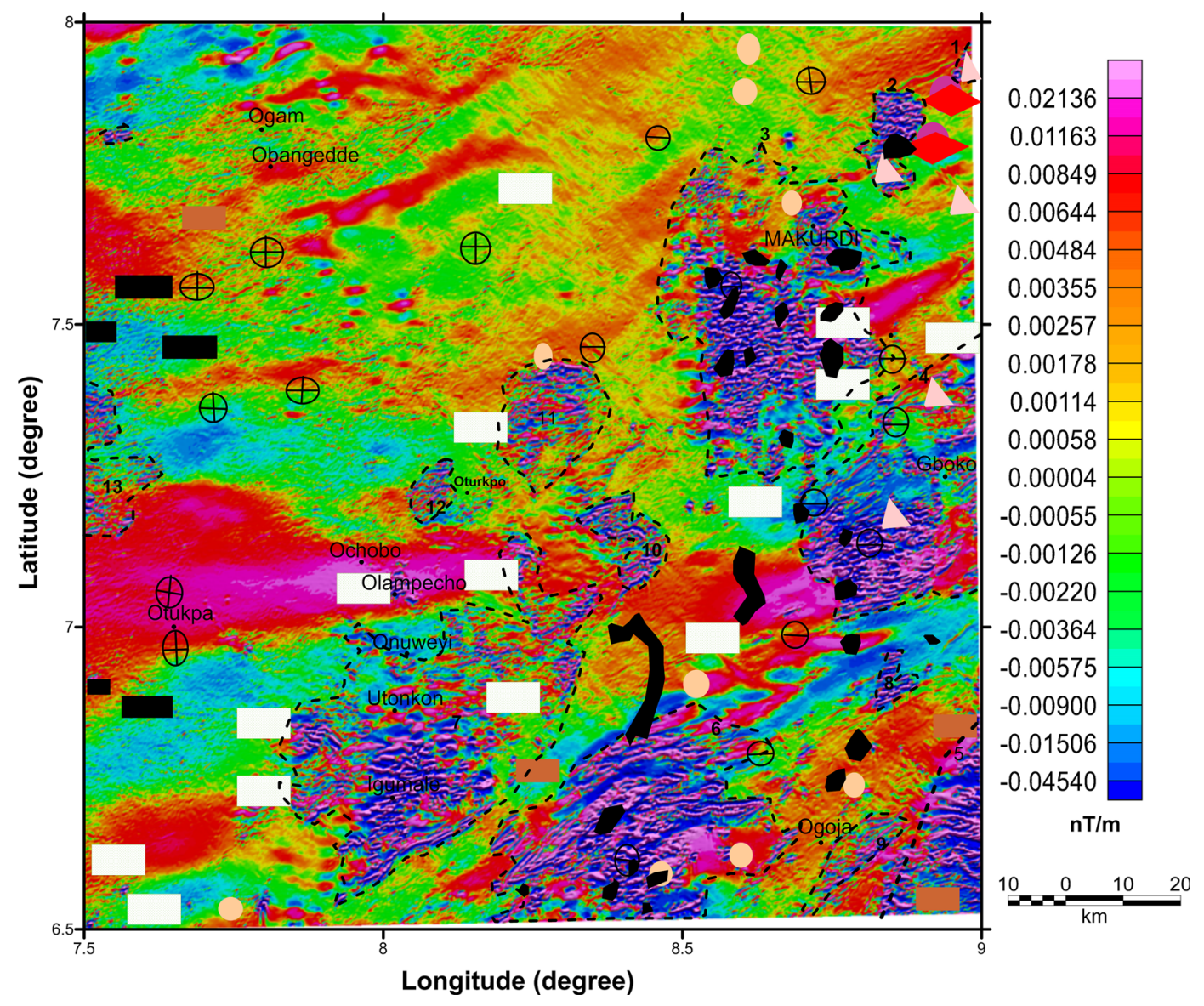

Figure 6. First vertical derivative map of the study area.

According to Blakely (1995), grid size of 5-6 times the expected depth is required for efficient estimation of depth to top of magnetic sources. On the basis of this, we have divided the RTP-TMI grid into 25 sub-grids (blocks) of $50 \times 50$ $\mathrm{km}$ with $50 \%$ overlap. Each grid is processed to remove the first order trend based on edge points using $10 \%$ square maximum entropy expansion. The logarithmic power of the spectrums against the wave number are obtained. The depth estimates of each section can be obtained by substituting the result of the slope of each of the section in the following relationship

$$
z=\frac{-m}{4 \pi}
$$

where $m$ is the slope and $z$ is the depth (Khalil et al. 2016). The estimated depth results are interpreted in terms of the magnetic basement and shallow (intrusive) basement. Figure 9 shows the power spectrum of four blocks, superimposed on them the estimated magnetic basement depth $(\mathrm{km})$ and the shallow depth (depth to top of intrusive) with respect to the mean sea level. We superimposed the estimated basement depth onto the geological map (figure 10) together with its contour plot. Table 1 shows the estimated basement depth and the shallow depth (depth to top of intrusive) bodies.

From the present magnetic data, we calculated the basement of magnetic sources between 2.1 and $6 \mathrm{~km}$. The dominant basement depth within the area are $3.5 \mathrm{~km}$ observed in blocks (B17, B23 and B25) and $5 \mathrm{~km}$ observed in blocks (B8, B15, B18 and B19). The shallow depth values vary between 0.24 and $1.2 \mathrm{~km}$. These depths are scattered and could be interpreted as the depth to top of intrusions at various location.

\section{Analysis of airborne gravity data}

Airborne Bouguer gravity data is collected for the study area from Nigerian Geological Survey Agency (NGSA). The data is acquired at a terrain 


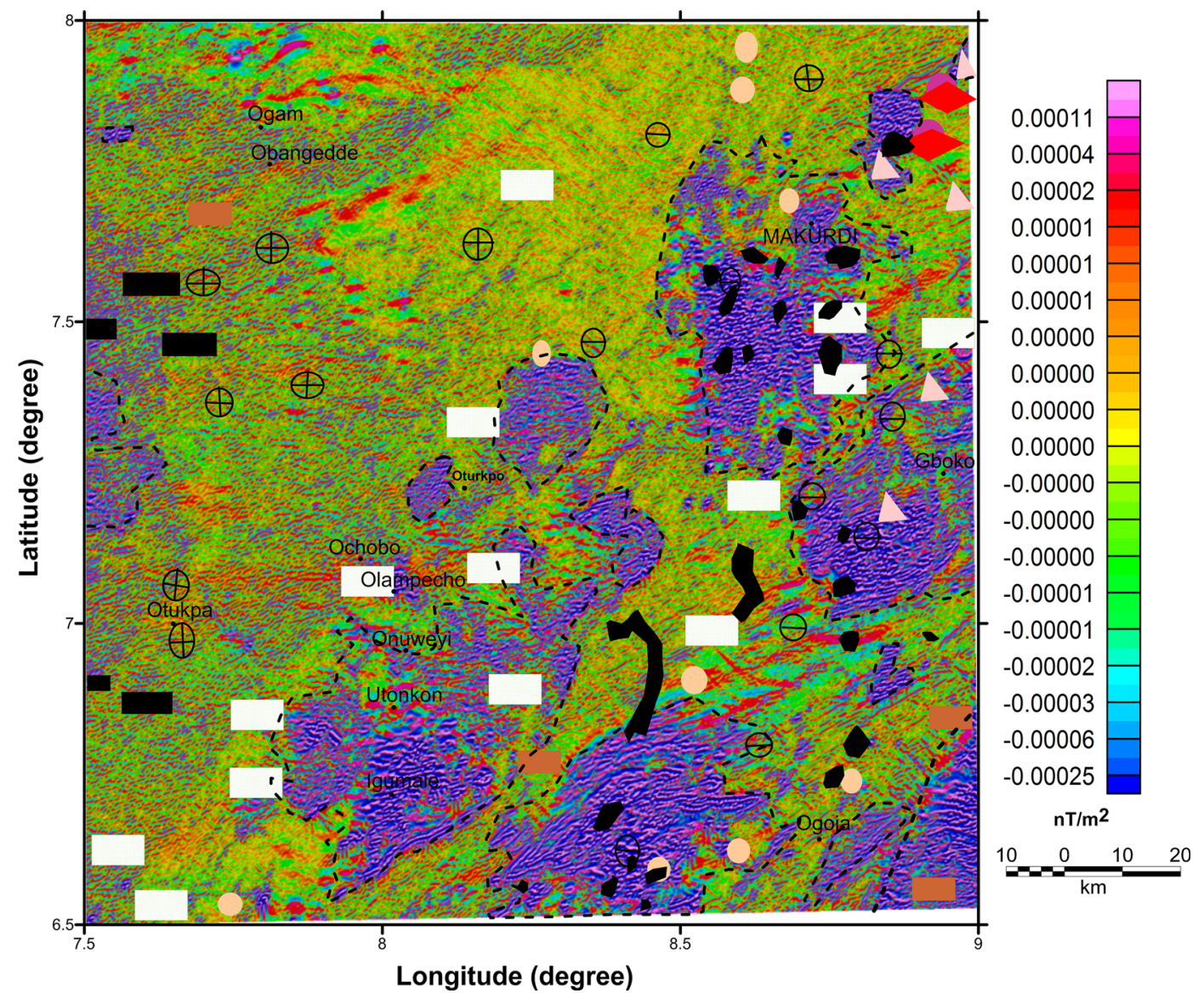

Figure 7. Second vertical derivative map of the study area.

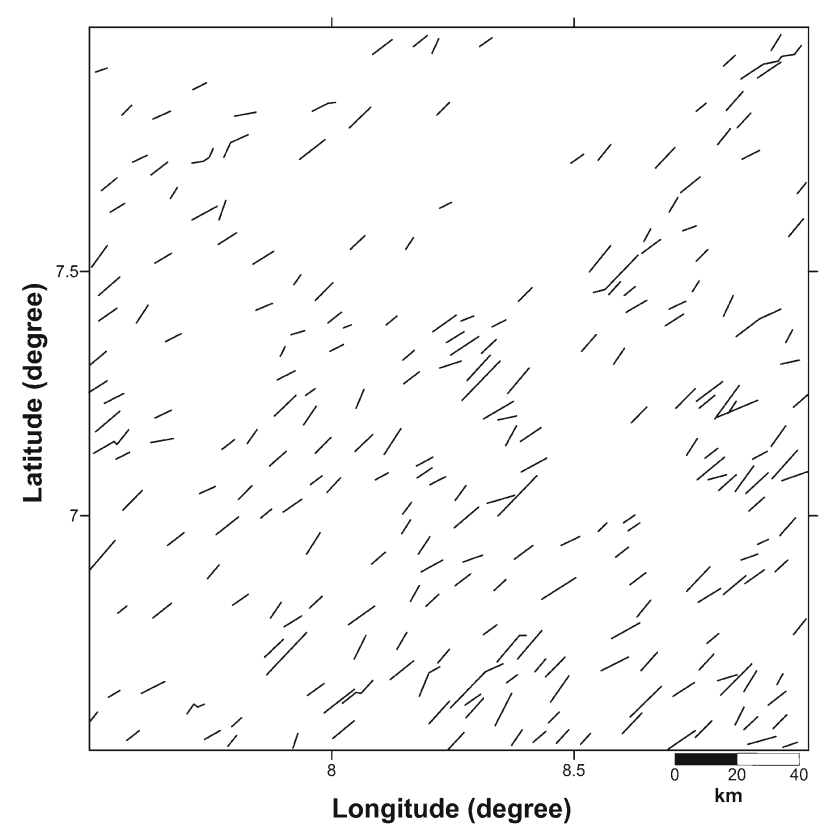

Figure 8. Interpreted magnetic lineament from second vertical derivative map.

clearance of $80 \mathrm{~m}$, along NE-SW oriented flight lines with $4000 \mathrm{~m}$ flight line spacing. The data is available in digitized sheet maps. The survey was flown and corrected by Fugro Airborne Surveys in 2010. Figure 11 shows the complete Bouguer anomaly map of the study area. The observed positive gravity anomalies in this area could be interpreted due to the zones of intrusions and shallow basement (Cratchley and Jones 1965; Adighije 1981; Ajayi and Ajakaiye 1981; Agagu and Adighije 1983). The negative anomalies could be a signature of sedimentary basins or area of thick Cretaceous sediments.

\subsection{Forward modelling}

Here forward modelling is done to generate the synthetic gravity anomalies of given depth of sedimentary basin using equation given in Chakravarthi (1995), where density contrasts $\Delta \rho$ and parabolic density variation $\alpha$ are known. The analytical gravity expression $\Delta g(0)$ at any point on the principal profile of a $2 \mathrm{D}$ arbitrary shaped body with parabolic density contrast using polygon approach has been used (Talwani et al. 1959). The polygonal concept of parabolic density function is 


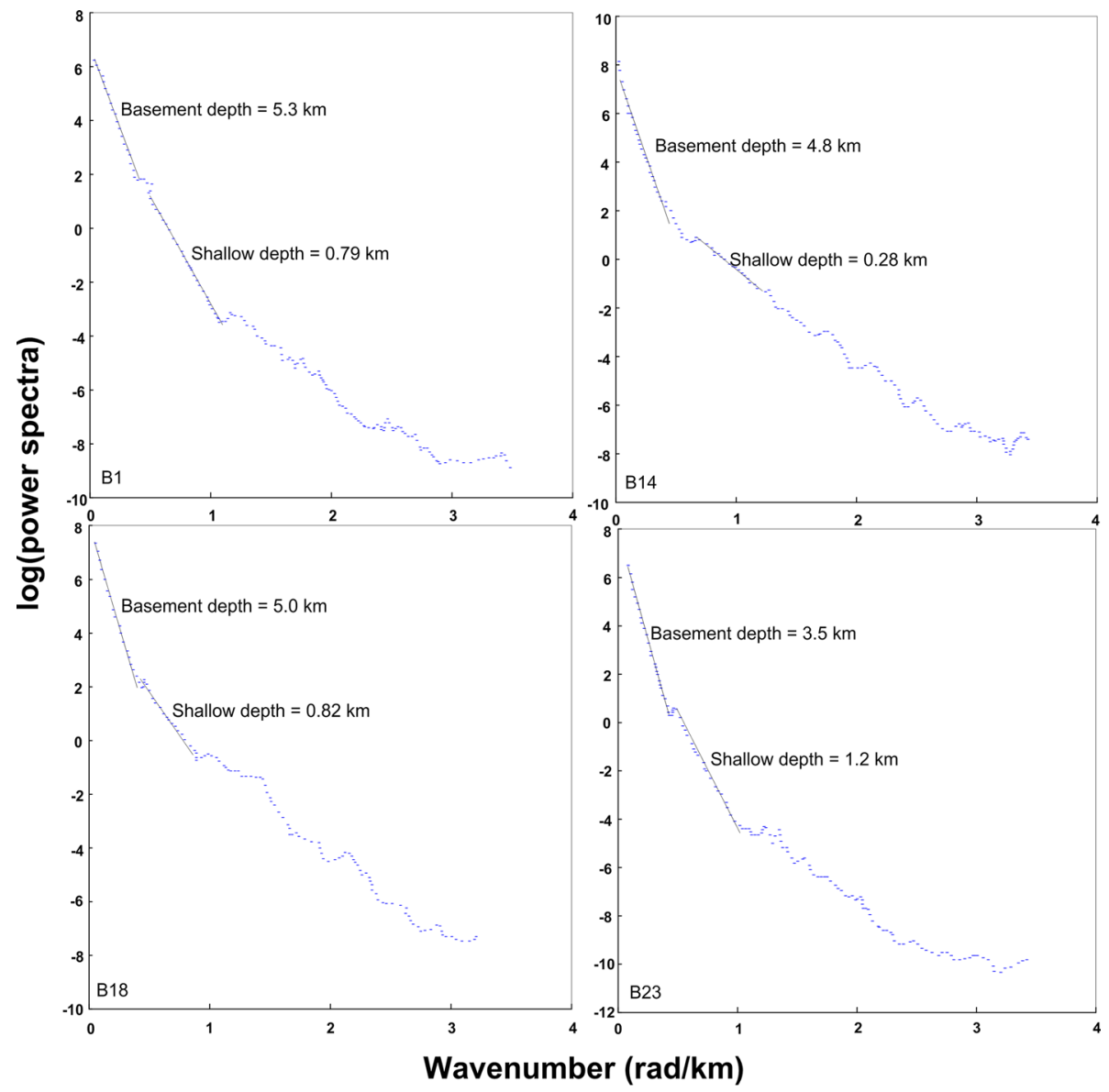

Figure 9. Example plots of $\log$ (power spectrum)/wave number $(\mathrm{rad} / \mathrm{km})$ of some blocks (B1, B14, B18 and B23) used in the study.

defined as (Rao et al. 1993, 1994; Chakravarthi et al. 2001)

$$
\Delta \rho(z)=\frac{\Delta \rho_{0}^{3}}{\left(\Delta \rho_{0}-\alpha z\right)^{2}}
$$

where $\Delta \rho(z)$ is the density contrast at any depth $(z), \Delta \rho_{0}$ is the density contrast extrapolated to the ground surface at $z=0$ and $\alpha$ is constant.

\subsection{Inverse modelling}

\subsubsection{Particle swarm optimization (PSO)}

PSO (Kennedy and Eberhart 1995), a global optimization method, is one of the naturally inspired metaheuristic algorithms using the behaviour of bird flocks and fish schools searching for food (Pallero et al. 2015; Ekinci 2016; Essa and Elhussein 2018). The algorithm can be elucidated considering a community of $N$ number of individuals (swarms) searching for exit door in the search space. Initially, each randomly positioned individual has a velocity that controls its movement in search space. The velocity of an individual depends on its current position and best position achieved by the community in the search space. This method is generally considered simple in concept, easy to implement and computationally efficient (Eberhart and Kennedy 1995; Eberhart and Shi 2001; El-Kaliouby and Al-Garni 2009) having the advantage of not requiring any training, which is a significant time consuming step. The main objective of each individual is to reach the door as soon as possible. The distance between the individual and the door is analogous to the misfit function (RMS error) in the inverse problems. Each iteration updates the location of each individual that corresponds to possible model taking into account its best position achieved so far ( $P_{\text {best }}$ model $)$ and the best position achieved by any individual of the community ( $G_{\text {best }}$ model). The velocity and position of the particle is updated using the following equations (Santos 2010; Roshan and Singh 2017) 


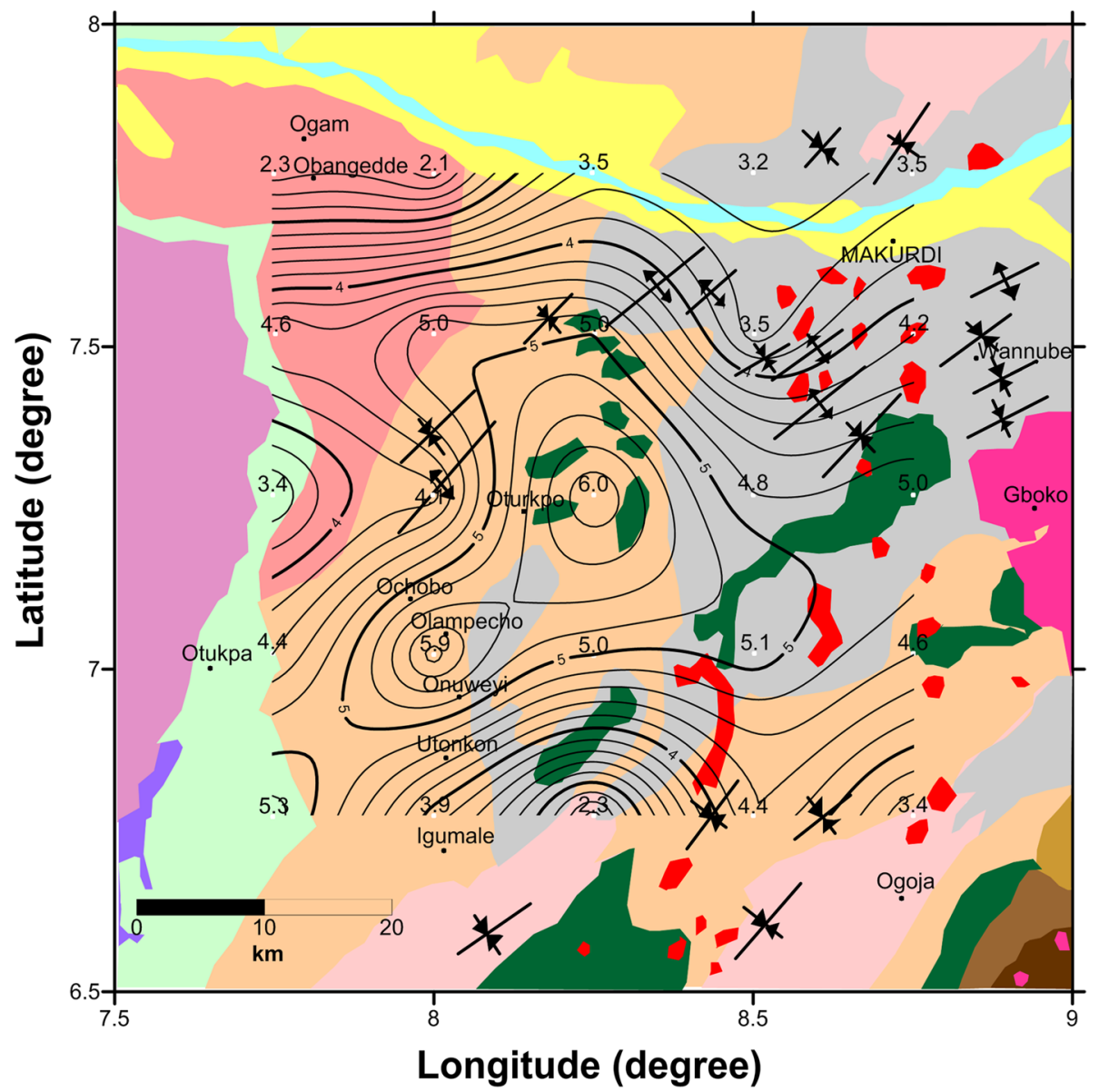

Figure 10. Geotectonics sketch map showing the estimated magnetic basement values. Superimposed on it, is the contour map of the magnetic basement estimated in the area.

$$
\begin{aligned}
v_{i}^{k+1}= & w v_{i}^{k}+c_{1} \operatorname{rand}_{()}^{*}\left(P_{\text {best }-i}^{k}-x_{i}^{k+1}\right) \\
& +c_{2} \operatorname{rand}_{()}^{*}\left(G_{\text {best }}^{k}-x_{i}^{k+1}\right)
\end{aligned}
$$

and

$$
x_{i}^{k+1}=x_{i}^{k}+v_{i}^{k+1},
$$

where, $v_{i}^{k}$ is the velocity of $i$ th particle at $k$ th iteration, $x_{i}^{k}$ represents current position of $i$ th particle at $k$ th iteration, $\operatorname{rand}()$ is a random number in the range of 0 and 1 . The constants $c_{1}$ and $c_{2}$ are known as cognitive and social coefficients, respectively and $w$ is an inertia weight.

\subsubsection{Global particle swarm optimization}

Global particle swarm optimization (GPSO) algorithm is improved version of PSO that is efficient and capable of finding the global optimal solution in very less number of iterations and also avoid trapping in local minima than the standard PSO (Jamian et al. 2014). The algorithm is a popular optimization method that is widely used in various applications, due to its simplicity and capability of obtaining optimal results (Jamian et al. 2014; Singh and Biswas 2016). Updating process of PSO uses only those $G_{\text {best }}$ values having better results while remaining $G_{\text {best }}$ values are terminated. This means that all $G_{\text {best }}$ achieved in the previous iteration are not participating in taking decision for the current results. In GPSO, previous knowledge and experience guides to take accurate decision for optimum results. Therefore, $G_{\text {best }}$ randomly selected among all the previous $G_{\text {best }}$ values and used to update the velocity of the particle is called $E_{\text {best }}$. The acceleration coefficient for $E_{\text {best }}$ is obtained by averaging cognitive and social constant parameter values. Thus, the new velocity that updates the next position of the particle is given as: 
Table 1. Estimated basement depth

\begin{tabular}{|c|c|c|}
\hline $\begin{array}{l}\text { Block } \\
\text { number }\end{array}$ & $\begin{array}{l}\text { Depth (magnetic } \\
\text { basement) }(\mathrm{km})\end{array}$ & $\begin{array}{c}\text { Shallow } \\
\text { depth }(\mathrm{km})\end{array}$ \\
\hline $\mathrm{Bl}$ & 5.3 & 0.79 \\
\hline B2 & 3.9 & 0.3 \\
\hline B3 & 2.3 & 0.33 \\
\hline B4 & 4.4 & 0.65 \\
\hline B5 & 3.4 & - \\
\hline B6 & 4.6 & 0.28 \\
\hline B7 & 5.1 & 0.85 \\
\hline B8 & 5.0 & 0.29 \\
\hline B9 & 5.9 & 0.31 \\
\hline B10 & 4.4 & 0.42 \\
\hline B11 & 3.4 & 0.25 \\
\hline B12 & 4.1 & 0.24 \\
\hline B13 & 6.0 & 0.7 \\
\hline B14 & 4.8 & 0.28 \\
\hline B15 & 5.0 & 0.27 \\
\hline B16 & 4.2 & - \\
\hline B17 & 3.5 & 0.66 \\
\hline B18 & 5.0 & 0.82 \\
\hline B19 & 5.0 & 0.29 \\
\hline B20 & 4.6 & 0.25 \\
\hline B21 & 2.3 & 0.32 \\
\hline B22 & 2.1 & 0.61 \\
\hline B23 & 3.5 & 1.2 \\
\hline B24 & 3.2 & 0.34 \\
\hline B25 & 3.5 & 0.24 \\
\hline
\end{tabular}

$$
\begin{aligned}
v_{i}^{k+1}= & w v_{i}^{k}+c_{1} \operatorname{rand}_{()}^{*}\left(P_{\text {best }-i}^{k}-x_{i}^{k+1}\right) \\
& +c_{2} \operatorname{rand}_{()}^{*}\left(G_{\text {best }}^{k}-x_{i}^{k}\right) \\
& +c_{3} \operatorname{rand}_{()}^{*}\left(E_{\text {best }}^{k}-x_{i}^{k}\right)
\end{aligned}
$$

where the last term is called improvement factor defined as (Jamian et al. 2014):

$$
\begin{aligned}
I F & =c_{3} \operatorname{rand}_{()}^{*}\left(E_{\mathrm{best}}^{k}-x_{i}^{k}\right) \\
& =\left[\frac{c_{1}+c_{2}}{2}\right] * \operatorname{rand}_{()}^{*}\left(E_{\text {best }}^{k}-x_{i}^{k}\right) .
\end{aligned}
$$

There is a conceptual difference between $E_{\text {best }}$ and $G_{\text {best }}$. The $G_{\text {best }}$ values for the current iteration are determined by successive comparison of previous $G_{\text {best }}$ values. Therefore, the possibility of having similar $G_{\text {best }}$ values is zero, whereas $E_{\text {best }}$ is randomly chosen value among the $G_{\text {best }}$ values. Here $I F$ significantly helps the algorithm to find next accurate particles' position. Thus $I F$ and $E_{\text {best }}$ makes the algorithms more powerful and efficient tool to fast convergence that improves the results obtained from PSO.

The RMS error is calculated from the following equation (Santos 2010)

$$
\operatorname{misfit}(\%)=\frac{100}{N} \sqrt{\sum_{i}^{N}\left(\frac{v_{i}^{o}-v_{i}^{c}}{v_{i}^{o}}\right)^{2}},
$$

where $N$ is the number of iteration, $v_{i}^{o}$ and $v_{i}^{c}$ are the observed and GPSO calculated gravity anomaly, respectively.

\subsection{Description of the main program}

The computer program inverSEDP for GPSO method has been developed in MATLAB environment to invert the gravity anomalies of density interfaces with parabolic density contrast. The input to the program consists of the number of observations $(n)$, the density contrast observed at the ground surface $(\Delta \rho)$, the constant alpha $(\alpha)$ of the parabolic density function, the distance $(x)$ and observed gravity anomaly $\left(g_{\text {obs }}\right)$ at each anomaly point. The GPSO technique requires upper and lower search range of depth and an arbitrary depth values between the search range, number of iterations and number of models and learning parameter as inputs. The program calculates forward models in given search bound then compare with the previous models and if present model is more accurate and close to the true model then save it. In this way, it minimizes the misfit error. forwardgrav, alter, change, mod, objective, output, gr2dpol used as function file of the program. The gr2dpol function file used to calculate theoretical gravity anomalies of a density interface at each anomaly point on the profile and return to the main program. The process continues until the specified number of iterations is completed. The output consists of the depth of the density interface in $\mathrm{km}$ and the calculated anomaly in mGal.

\subsection{Application of global particle swarm optimization to synthetic gravity anomalies}

Initially, both algorithms, PSO and GPSO were performed and compared their performance on synthetic gravity anomalies at 100 independent iterations after the tuning of the PSO learning/controlling parameter (i.e., $c_{1}, c_{2}, c_{3}$ and $w$ ). The learning parameter values have been taken 


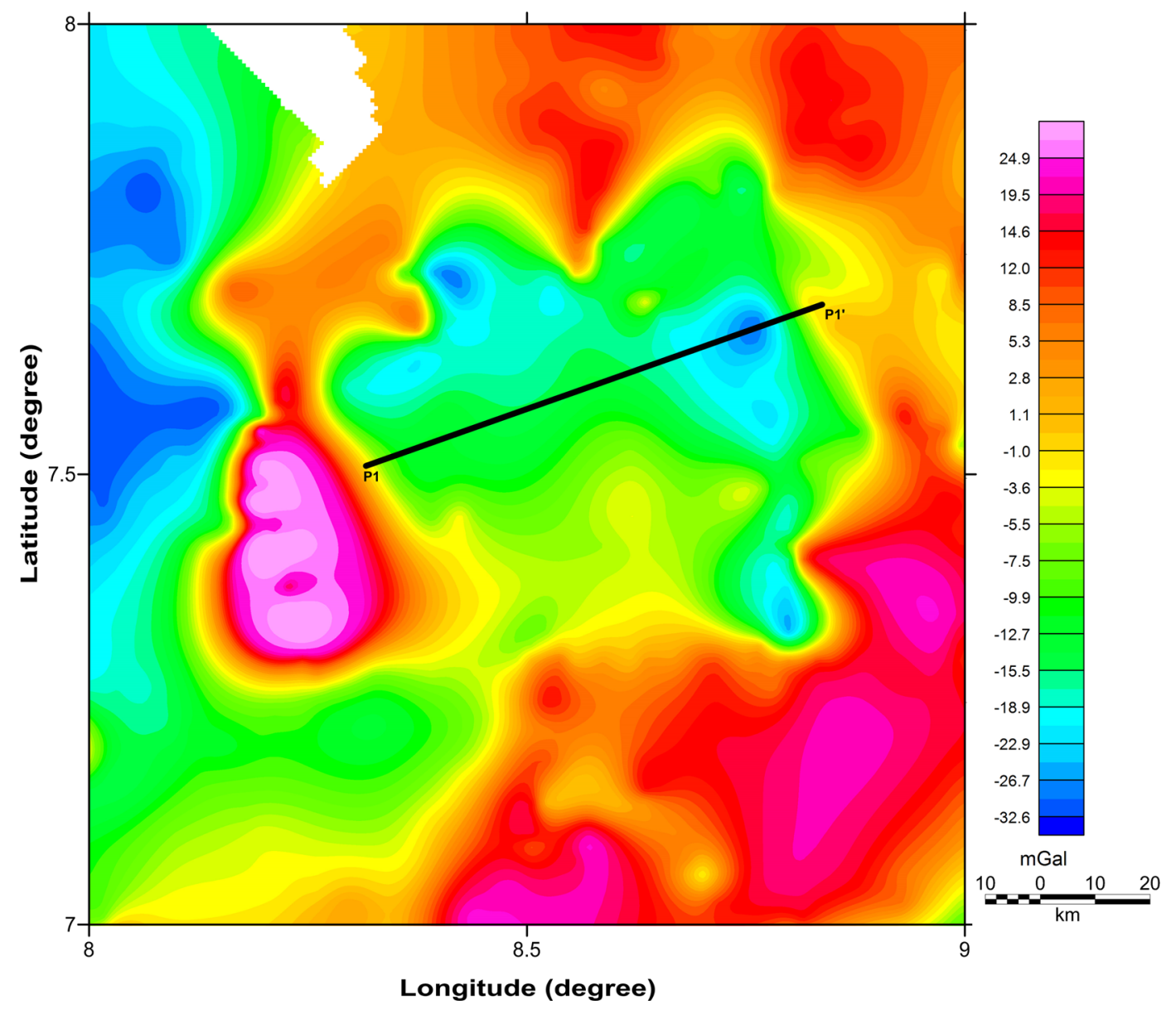

Figure 11. Complete Bouguer anomaly map of the study area. The line P1P1' shows the profile taken for the $2 \mathrm{D}$ inversion.

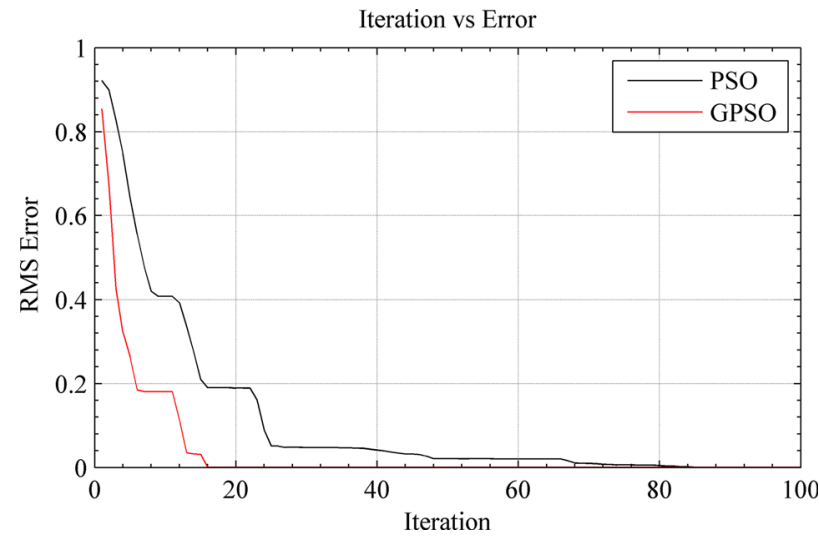

Figure 12. Convergence performance of PSO and GPSO.

$c_{1}=c_{2}=c_{3}=1.4$ and $w=0.7$ for our case. We have used 100 models for both cases. Figure 12 shows the convergence performance of PSO and GPSO. It is clear from the figure that GPSO converges faster than the PSO. PSO converged at 84 iterations with RMS error of $0.089 \%$ whereas GPSO converged at 16 iteration with RMS error of $0.0017 \%$. On the basis of their performance, GPSO was validated and tested on synthetic gravity anomalies and then applied to field gravity anomalies over parts of Lower Benue Trough, Nigeria.

Introducing density contrast for different depth $\Delta \rho(z)$, depth of the basin $(z)$ and value of parabolic density constant $(\alpha)$, we calculated the synthetic gravity anomalies at different depth points on the principal profile.

In generating the gravity anomalies along a profile, we assigned the value of density contrast on the surface $\Delta \rho_{0}=-0.65 \mathrm{gm} / \mathrm{cm}^{3}$ and constant $\alpha=0.2 \mathrm{gm} / \mathrm{cm}^{3} / \mathrm{km}$ of the parabolic density function. The density contrast variation with depth has been calculated by equation (3) and then synthetic gravity anomalies have been generated using the equation as proposed by Rao et al. (1993). The profile length of $9.5 \mathrm{~km}$ has been taken for the study. Thirteen data points have been taken at 0.5 and $1.0 \mathrm{~km}$ interval alternatively. Now GPSO method has been applied over synthetic gravity anomalies 


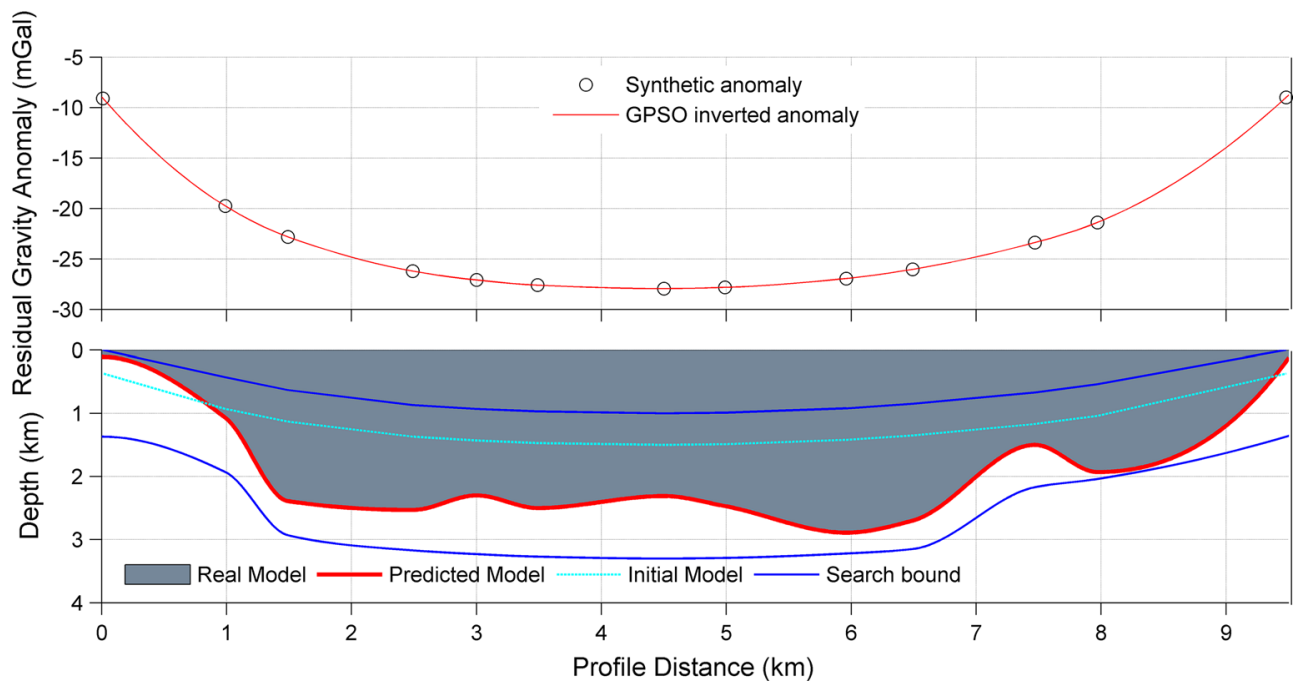

Figure 13. Synthetic gravity anomaly and GPSO inverted anomaly of the sedimentary basin and corresponding depth (km). RMS error $=0.028$.
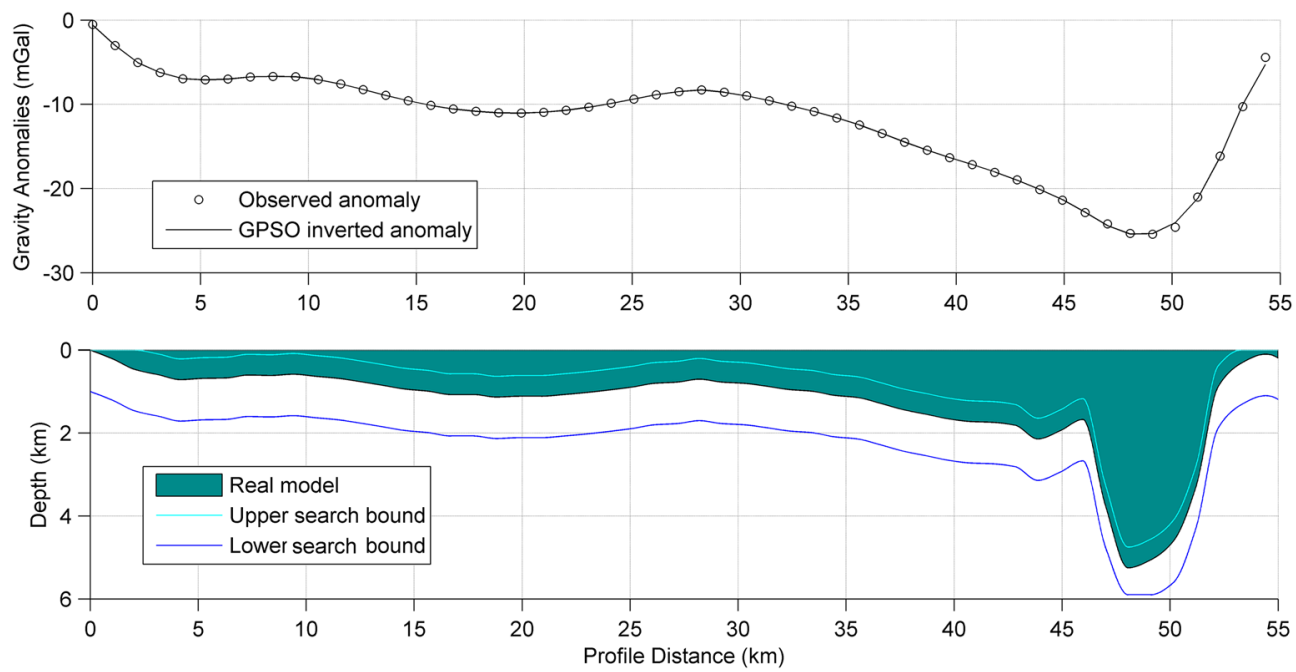

Figure 14. 2D inverted gravity anomaly along P1P1' using GPSO.

of the basin to test the algorithms. The synthetic anomalies and GPSO inverted anomalies have been plotted in the same figure 13 and the corresponding depth section has been shown in subplot just below the anomaly plot.

\subsection{Application to field data}

We applied GPSO method over the airborne Bouguer gravity data of the parts of Lower Benue Trough, Nigeria to find out the basement depth of sedimentary basin. Figure 11 shows the location of $\mathrm{P} 1 \mathrm{P} 1^{\prime}$ profile taken at one kilometre interval. We applied GPSO algorithm to find the depth of basement of sedimentary basin over the profile. The density contrast variation taken for $\mathrm{P} 1 \mathrm{P} 1^{\prime}$ is $\Delta \rho_{0}=-0.27 \mathrm{gm} / \mathrm{cm}^{3}$ and density contrast variation is $\alpha=0.015 \mathrm{gm} / \mathrm{cm}^{3} / \mathrm{km}$. We applied the proposed algorithms and the maximum depth has been calculated $(5.25 \mathrm{~km})$ with RMS error of 0.25 (figure 14). The optimized depth, observed and calculated gravity anomalies has been shown in figure 14. Using the depth information calculated by GPSO method and density information we have done 2D modelling by Oasis Montaj 8.1 (Geosoft). The maximum depth $(5 \mathrm{~km})$ obtained by Geosoft also supports the depth calculated by the GPSO method (figure 15). 


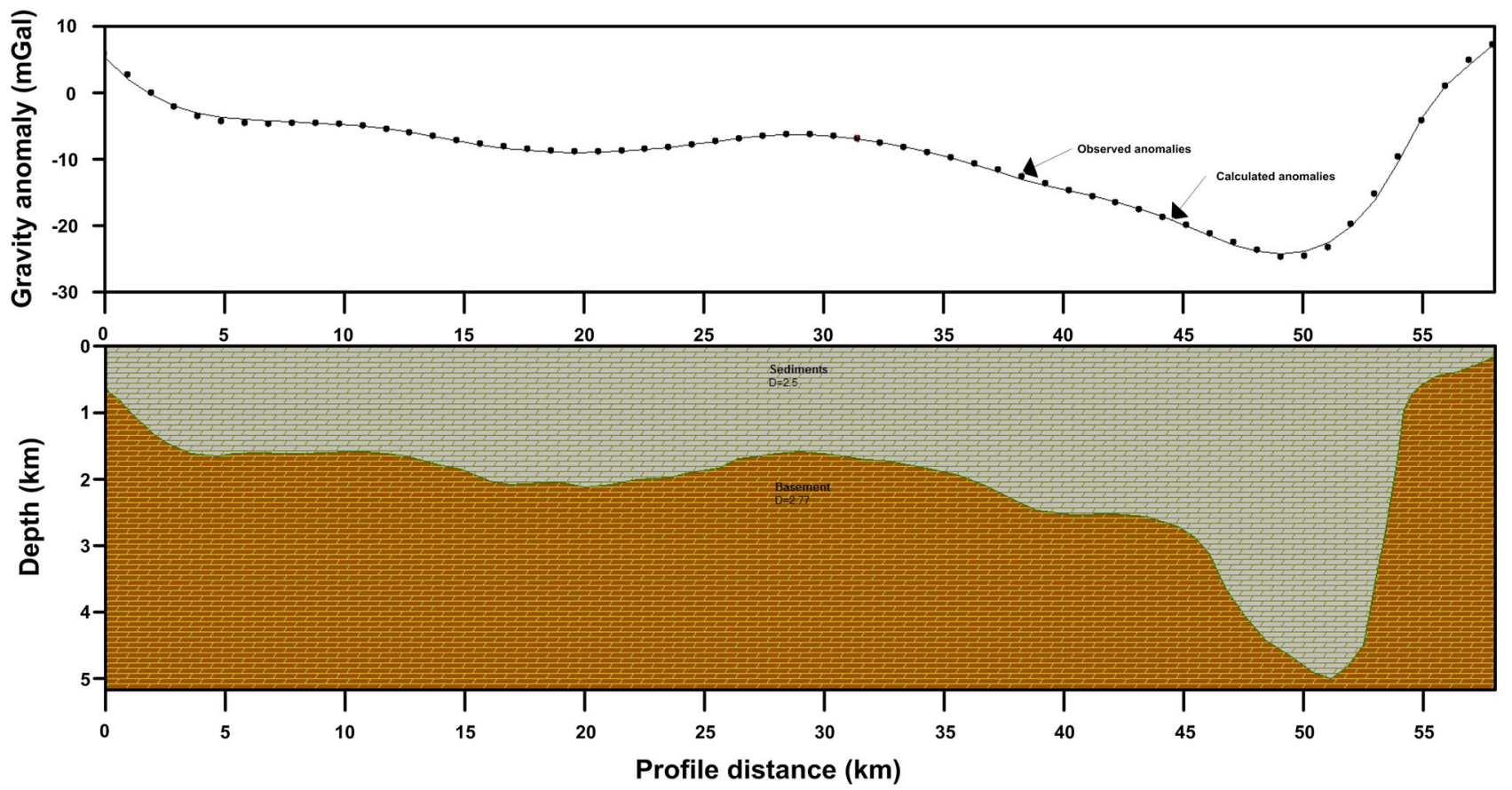

Figure 15. 2D inverted gravity anomaly along $\mathrm{P} 1 \mathrm{P} 1^{\prime}$ using Geosoft.

\section{Discussion and conclusions}

Analysis of the high-resolution aeromagnetic data of the present study area in relation to the geological information, could be interpreted that, the high magnetic anomalies observed in the area correlated to zones of volcanic intrusions (Ofoegbu 1984). The intrusions (at various depth) appeared to spread over almost $70-75 \%$ of the area beyond their exposure on the geological map. The intrusions invaded the Cretaceous sedimentary rocks and could also be found within the basement rocks (Ofoegbu 1984). The intrusions could be the contributing factor to the positive gravity anomaly observed in the area (figure 11) (Cratchley and Jones 1965; Adighije 1981; Ajayi and Ajakaiye 1981).

The analysis of magnetic lineaments from the derivative aero-data revealed the dominant NESW and ENE-WSW trends of lineaments and subordinate $\mathrm{N}-\mathrm{S}$ and $\mathrm{ESE}-\mathrm{WNW}$ trends (figure 8). The dominant NE-SW trends were observed by (Anudu et al. 2014; Oha et al. 2016) in their studies around the north-south and eastern part of this area. The NE-SW trends are interpreted to correlate with the deep seated faults (Oha et al. 2016), which may have been reactivated by NESW sinistral shear during the opening of the trough (Guiraud and Maurin 1992; Anudu et al. 2014).
The NE-SW trend is paralleled to the trough's orientation and it is assumed to control the dextral shear zones of the late Pan-African age (Maurin et al. 1986; Anudu et al. 2014). The NE-SW trends could be interpreted as the NE-SW trending Neoproterozoic tectonic units of the Brasiliano/PanAfrican orogen (de Castro et al. 2012; Anudu et al. 2014). The ENE-WSE trends were also observed and delineated in (Anudu et al. 2014). The trends represent the mega shear zones in Africa called the Central African Shear Zone (CASZ), which resulted from the important tectonic movements that occurred during the Pan-African orogenic cycle (Moreau et al. 1987). The ENE-WSW is also a dextral shear zone that is related to the wider mylonite belts pre-dating at the Cretaceous times, the opening of the South Atlantic Ocean (Jorgensen and Bosworth 1989; Djomani et al. 1995). The N-S lineaments are minor trends. Anudu et al. (2014) in their studies in the lower and middle parts of Benue Trough also delineated the N-S lineaments and suggested them as the minor trends in the area. Their formation may be associated to either the migration of the African plate over the mantle plume or shear movements along the pre-existing ENE-WSW faults in the Pan-African basement (Djomani et al. 1995).

We have estimated the basement depth of magnetic sources from the RTP-TMI of the 
high-resolution aeromagnetic data of lower Benue Trough using spectral analysis. The basement depth estimated from the magnetic data vary between 3.5 and $5 \mathrm{~km}$. Basement depth from other studies showed depths between 2 and $3 \mathrm{~km}$ (Benkhelil 1988) around Ogoja from gravity data. Ofoegbu and Onuoha (1991) estimated the basement depth of 1.5 and $2.5 \mathrm{~km}$ around the same Ogoja from magnetic data. In our present study, we estimated the basement depth of $3.4 \mathrm{~km}$ north of the Ogoja area. Oha et al. (2016) from magnetic data of parts of the present study area, estimated the basement depth of $2.14 \mathrm{~km}$ south of block (B1) where we estimated the basement depth of $5.3 \mathrm{~km}$. They also estimated depths of 2.29 and $2.88 \mathrm{~km}$ corresponding to block (B3) in the present study $(2.3 \mathrm{~km})$ and depth of $3.64 \mathrm{~km}$ corresponding to block (B4) in which we estimated the basement depth of $4.4 \mathrm{~km}$.

From the airborne Bouguer gravity data of parts of the study area, we identified sub-basins around Makurdi over the gravity low. The low gravity correlates with low magnetic anomaly (figure 5). The depth to basement of the sedimentary basins are estimated using GPSO algorism and Geosoft. The basement of the sedimentary subbasin around the Makurdi is estimated as 5.25 $\mathrm{km}$ using GPSO and $5 \mathrm{~km}$ using Geosoft. This profile is between blocks (B16, B17 and B25) on the magnetic data (figure 2). The depth estimated within these blocks vary between 3.5 and $4.2 \mathrm{~km}$.

High-resolution aeromagnetic data can be very useful for hydrocarbon as well as mineral exploration. In the present study, we present a more detailed interpretation of the magnetic data of this area in terms of the real geology of the area.

\section{Acknowledgements}

The first author wishes to acknowledge the Tertiary Education Trust Fund (TET Fund), Nigeria through Modibbo Adama University of Technology, Yola (Nigeria) for financial support of his $\mathrm{PhD}$ research. The data to this research was arranged through the Nigerian Geological Survey Agency (NGSA), Abuja office, Nigeria. We are indebted to Dr Arkoprovo Biswas, the associate editor and the two anonymous reviewers for the constructive comments and suggestions on the paper.

\section{References}

Abdelrahman E M, Abo-Ezz E R, Essa K S, El-Araby T M and Soliman K S 2007 A new least-squares minimization approach to depth and shape determination from magnetic data; Geophys. Prospect. 55 433-446.

Abdelrahman E M, Abo-Ezz E R and Essa K S 2012 Parametric inversion of residual magnetic anomalies due to simple geometric bodies; Explor. Geophys. 43 178-189.

Abdelrahman E M and Essa K S 2015 A new method for depth and shape determinations from magnetic data; Pure Appl. Geophys. 172 439-460.

Abo-Ezz E R and Essa K S 2016 A least-squares minimization approach for model parameters estimate by using a new magnetic formula; Pure Appl. Geophys. 173 12651278 .

Adighije C 1981 A gravity interpretation of the Benue Trough, Nigeria; Tectonophys. 79 109-128.

Agagu O K and Adighije C I 1983 Tectonic and sedimentation framework of the lower Benue Trough, southeastern Nigeria; J. Afr. Earth Sci. 1(3-4) 267-274.

Ajayi C O and Ajakaiye D E 1981 The origin and peculiarities of the Nigerian Benue Trough: Another look from recent gravity data obtained from middle Benue; Tectonophys. 80 285-303.

Akande O, Zentelli M and Reynolds P H 1989 Fluid inclusion and stable isotope studies of $\mathrm{Pb}-\mathrm{Zn}$-fluorite-barite mineralization in lower and middle Benue Trough, Nigeria; Mineral Deposit 24 183-191.

Ali M Y, Watts A B and Farid A 2014 Gravity anomalies of the United Arab Emirates: Implications for basement structures and infra-Cambrian salt distribution; GeoArab. 19(1) 85-112.

Anudu G K, Stephenson R A and Macdonald D I M 2014 Using high-resolution aeromagnetic data to recognize and map intra-sedimentary volcanic rocks and geological structures across the cretaceous middle Benue Trough, Nigeria; J. Afr. Earth Sci. 99 625-636.

Benkhelil J 1982 Benue Trough and Benue chain; Geol. Mag. 119 155-168.

Benkhelil J 1988 Structure et evolution geodynamiquedu basin intracontinental de la Benoue (Nigeria); Bull. Centres Rech. Explor. Pro. Elf-Afquitaine 1207 29-128.

Benkhelil J 1989 The origin and evolution of the Cretaceous Benue Trough (Nigeria); J. Afr. Earth Sci. 6 251-282.

Bhattacharyya B K 1965 Two dimensional harmonic analysis as a tool for magnetic interpretation; Geophysics 30829 857.

Biswas A 2016 Interpretation of gravity and magnetic anomaly over thin sheet-type structure using very fast simulated annealing global optimization technique; Model. Earth Syst. Environ. 2(1) 30.

Biswas A and Acharya T 2016 A very fast simulated annealing method for inversion of magnetic anomaly over semiinfinite vertical rod-type structure; Model. Earth Syst. Environ. 2(4) 198.

Blakely R J 1995 Potential theory in gravity and magnetic applications; Cambridge University Press, UK, $63 \mathrm{p}$.

Bott M H P 1960 The use of rapid digital computing methods for direct gravity interpretation of sedimentary basins; Geophys. J. Roy. Astron. Soc. 3 63-67. 
Chakravarthi V 1995 Gravity interpretation of nonoutcropping sedimentary basins in which the density contrast decreases parabolically with depth; Pure Appl. Geophys. 145 327-335.

Chakravarthi V, Singh S B and Babu G A 2001 INVER2DBASE - A program to compute basement depths of density interfaces above which the density contrast varies with depth; Comput. Geosci. 27 1127-1133.

Chakravarthi V and Sundararajan N 2005 Gravity modelling of $2^{1} / 2$ sedimentary basins - a case of variable density contrast; Comput. Geosci. 31 820-827.

Cordell L and Grauch V J S 1985 Mapping basement magnetization zone from aeromagnetic data in the San Juan Basin, New Mexico; In: The utility of regional gravity and magnetic anomaly maps (eds) Hinze and William J, Soc. Explor. Geophys., Tulsa, Oklahoma, 181-197.

Cratchley C R and Jones G P 1965 An interpretation of the geology and gravity anomalies of the Benue Valley Nigeria; Oversea Geological Survey London.

de Castro D I, Bezerra F H R, Sousa M O I and Fuck R A 2012 Influence of Neoproterozoic tectonic fabric on the origin of the Potiguar Basin, northeastern Brazil and its links with West Africa based on gravity and magnetic data; J. Geodyn. 54 29-42.

Djomani Y H P, Nnange J M, Diament M, Ebinger C J and Fairhead J D 1995 Effective elastic thickness and crustal thickness variations in west central Africa inferred from gravity data; J. Geophys. Res. 100 22047-22070.

Dobrin M B and Savit C H 1988 Introduction to geophysical prospecting; McGraw-Hill, New York, 867p.

Eberhart R C and Kennedy J 1995 A new optimizer using particle swarm theory; Proceedings of the sixth international symposium on micro machine and human science, IEEE service center, Piscataway, NJ, Nagoya, Japan, pp. 39-43.

Eberhart R C and Shi Y 2001 Particle swarm optimization: Developments, applications and resources; Proceedings of congress on evolutionary computation, IEEE service center, Piscataway, NJ, Seoul, Korea.

Ekinci Y L, Ertekin C and Yiğitbaş E 2013 On the effectiveness of directional derivative based filters on gravity anomalies for edge approximation: Synthetic simulations and a case study from the Aegean Graben System (Western Anatolia, Turkey); J. Geophys. Eng. 10(3) 035005.

Ekinci Y L and Yiğitbaş E 2015 Interpretation of gravity anomalies to delineate some structural features of Biga and Gelibolu Peninsulas and their surroundings (northwest Turkey); Geodin. Acta 27(4) 300-319.

Ekinci Y L 2016 MATLAB-based algorithm to estimate depths of isolated thin dike-like sources using higher-order horizontal derivatives of magnetic anomalies; Springerplus 51384.

El-Kaliouby H M and Al-Garni M A 2009 Inversion of selfpotential anomalies caused by 2D inclined sheets using neural networks; J. Geophys. Eng. 6 29-34.

Essa K S and Elhussein M 2017 A new approach for the interpretation of magnetic data by a $2 \mathrm{D}$ dipping dike; J. Appl. Geophys. 136 431-443.

Essa K S and Elhussein M 2018 PSO (Particle swarm optimization) for interpretation of magnetic anomalies caused by simple geometrical structures; Pure Appl. Geophys. 175(10) 3539-3553.
Garcia-Abdeslem J and Ness G E 1994 Inversion of the power spectrum from magnetic anomalies; Geophysics 59 391401.

Guiraud R and Maurin J C 1992 Early Cretaceous rifts of western and central Africa; Tectonophys. 213 153-168.

Jamian J J, Abdullah M N, Mokhlis H, Mustafa M W and Bakar A H A 2014 Global particle swarm optimization for high dimension numerical functions analysis; J. Appl. Math. 329193 1-14.

Jorgensen G J and Bosworth W 1989 Gravity modeling in the Central African Rift System, Sudan: Rift geometries and tectonic significance; J. Afr. Earth Sci. 8 283-306.

Kennedy J and Eberhart R 1995 Particle swarm optimization; IEEE Int. Conf. Neural. Netw. 4 19421948.

Khalil A, Abdel Hafeez T H, Saleh H S and Mohamed W H 2016 Inferring the subsurface basement depth and the structural trends as deduced from aeromagnetic data at West Beni Suef area, Western Desert, Egypt; NRIAG J. Astro. Geophys. 5(2) 380-392.

King L C 1950 Outline and disruption of Gondwanaland; Geol. Mag. 87 353-359.

Maluski H, Coulon C, Popoff M and Baudin P 1995 ${ }^{40} \mathrm{Ar} /{ }^{39} \mathrm{Ar}$ chronology, petrology and geodynamic setting of Mesozoic to early Cenozoic magmatism from the Benue Trough, Nigeria; J. Geol. Soc. London 152 311-326.

Maurin J C, Benkhelil J and Robineau B 1986 Fault rocks of the Kaltungo lineament, NE Nigeria and their relationship with Benue Trough tectonics; J. Geol. Soc. London 143 $587-599$.

Maurizio F, Tatina Q and Angelo S 1998 Exploration of a lignite bearing in northern Ireland, using ground magnetic; Geophysics 62 1143-1150.

MMSD (Ministry of Mines and Steel Development) 2010 Barites: Exploration opportunities in Nigeria; Nigerian Geological Survey Agency, Abuja, 12p.

Moreau C, Reynoult J M, Deruelle B and Robineau B 1987 A new tectonic model for the Cameroon Line, Central Africa; Tectonophys. 139 317-334.

Nabighian M N 1972 The analytic signal of two-dimensional magnetic bodies with polygonal cross-section: Its properties and use for automated anomaly interpretation; Geophysics 37(3) 507-517.

NGSA (Nigerian Geological Survey Agency) 2009 Geological and mineral resource map of Nigeria; Authority of the Federal Republic of Nigeria.

Nwachukwu S O 1972 The tectonic evolution of the southern portion of the Benue Trough, Nigeria; Geol. Mag. 109 411-419.

Ofoegbu C O 1984 Interpretation of aeromagnetic anomalies over Lower and Middle Benue Trough of Nigeria; Geophys. J. Roy. Astron. Soc. 79 813-823.

Ofoegbu C O 1985 Interpretation of an aeromagnetic profile across the Benue Trough of Nigeria; J. Afr. Earth Sci. 3(3) 293-296.

Ofoegbu C O and Onuoha K M 1991 Analysis of magnetic data over the Abakaliki anticlinorium of the Lower Benue Trough, Nigeria; Mar. Petrol. Geol. 8 174-183.

Oha I A, Onuoha K M, Nwegbu A N and Abba A U 2016 Interpretation of high resolution aeromagnetic data over 
southern Benue Trough, southeastern Nigeria; J. Earth Syst. Sci. 125 369-385.

Olade M A 1978 Early Cretaceous basalt volcanism and initial continental rifting in Benue Trough, Nigeria; Natur. Intern. J. Sci. 273 458-559.

Pallero J L G, Fernandez-Martinez J L, Bonvalot S and Fudym O 2015 Gravity inversion and uncertainty assessment of basement relief via Particle Swarm Optimization; J. Appl. Geophys. 116 180-191.

Phillips J D 1998 Processing and interpretation of aeromagnetic data from Santa Cruz Basin-Patahonia mountains area, south-central Arizona; US Geological Survey Open File Report, pp. 2-98.

Rao C V, Chakravarthi V and Raju M L 1993 Parabolic density function in sedimentary basin modelling; Pure Appl. Geophys. 140(3) 493-501.

Rao C V, Pramanik A G, Kumar G V R K and Raju M L 1994 Gravity interpretation of sedimentary basins with hyperbolic density contrast; Geophys. Prospect. 42 825839.

Roest W R, Verhoef J and Pilkington M 1992 Magnetic interpretation using the 3D analytic signal; Geophysics $\mathbf{5 7}$ $116-125$.

Roshan R and Singh U K 2017 Inversion of residual gravity anomalies using tuned PSO; Geosci. Instrum. Method. Data Syst. 6 71-79.

Rozimant K, Büyüksarac A and Bektaş Ö 2009 Interpretation of magnetic anomalies and estimation of depth of magnetic crust in Slovakia; Pure Appl. Geophys. 166 $471-484$
Salem A, Williams S, Fairhead J D, Ravat D and Smith R 2007 Tilt-depth method: A simple depth estimation method using first-order magnetic derivatives; Leading Edge 26 1502-1505.

Santos F A M 2010 Inversion of self-potential of idealized bodies' anomalies using particle swarm optimization; Comput. Geosci. 36 1185-1190.

Singh A and Biswas A 2016 Application of global particle swarm optimization for inversion of residual gravity anomalies over geological bodies with idealized geometries; Natur. Resour. Res., https://doi.org/10.1007/ s11053-015-9285-9.

Spector A and Grant F S 1970 Statistical model for interpreting aeromagnetic data; Geophysics 35 293-302.

Stoneley R 1966 The Niger delta region in the light of the theory of continental drift; Geol. Mag. 103 385-397.

Talwani M, Worzel J and Ladisman M 1959 Rapid gravity computations for two dimensional bodies with application to the Mendocino submarine fracture zone; J. Geophys. Res. 64(1) 49-59.

Telford W M, Geldart L P and Sheriff R E 1998 Applied geophysics; Springer, Berlin, 770p.

Uzuakpunwa A B 1974 The Abakaliki pyroclastics, eastern Nigeria: New age and tectonic implication; Geol. Mag. 111 $65-70$.

Verduzco B, Fairhead J D, Green C M and Mackenzie C 2004 New insights into magnetic derivatives for structural mapping; Leading Edge 23 116-119.

Wright J B 1968 South Atlantic continental drift and the Benue Trough; Tectonophys. 6 301-310.

Corresponding editor: ARKoprovo BiswaS 